\title{
THE ECOLOGICAL CONSEQUENCES OF HABITAT AND MICROHABITAT USE IN LIZARDS: A REVIEW
}

\author{
Geoffrey R. Smith ${ }^{1}$, Royce E. Ballinger ${ }^{2}$
}

1 Department of Biology, Denison University, Granville, OH 43023, USA

2 School of Biological Sciences, University of Nebraska, Lincoln, NE 68588-0118, USA

Abstract. We review the ecological consequences of habitat and microhabitat use in lizards. Different habitats have different biotic and abiotic properties and thus are likely to have different consequences for the lizards that occur in them. Individual performance and life histories are influenced by habitat use, particularly when habitats differ in thermal characteristics that may influence physiological processes or constrain activity. We know relatively little about how the effects of habitat use on individual performance translate into population dynamics. We do know that the ability of lizards to use particular habitats can influence the persistence of populations in the face of habitat changes. Community-level processes (e.g., competition) and community structure (e.g., diversity) can be influenced by habitat use in lizards, often by habitat use facilitating co-existence of two or more potentially competing species. We know relatively little about how other community processes, such as predation and parasitism, are influenced by habitat use.

Why do animals occur where they do? Beyond the basic requirement that an individual must be able to survive, different locations or habitats may provide different conditions for an individual's existence. Thus, another question arises: What are the consequences of the choice of habitat or microhabitat on the biology and ecology of the organism being considered? From an ecological point of view, habitat selection can influence physiological processes (Huey, 1991), population dynamics (Holt, 1987; Pulliam and Danielson, 1991), and community level processes (Morris, 1988; Rosenzweig, 1991).

Lizards are an excellent group of organisms with which to examine the ecological consequences of habitat and microhabitat use. First, there is a relatively long history of studying habitat and microhabitat use in lizards, at least qualitatively (reviewed by Heatwole, 1977). Second, lizard ecology and physiology is well studied, at least for some species (see papers in Milstead, 
1967; Gans and Pough, 1982a,b; Huey et al., 1983; Gans and Huey, 1988; Vitt and Pianka, 1994). Finally, recent studies have begun to examine the relationship between lizards and their environments in greater detail (see below) and provide a means to assess the role of habitat and microhabitat use in a lizard's ecology. There is also a practical reason for looking at the ecological consequences of habitat and microhabitat use in lizards, and that is the on-going alterations of the environment by humans. We need to understand the role of habitat and microhabitat use in lizard ecology to be able to assess the potential impacts of such environmental changes and to suggest possible conservation measures.

Before we begin our review of habitat use in lizards, it is necessary for us to define what we mean by "habitat". Habitat can mean a number of things and its meaning can depend heavily on the scale one is considering (see Morris, 1987a,b, 1992 for discussions of the interaction of scale and habitat use). For the majority of this review, habitat is used in a broader sense to include the general type of area in which an individual occurs (e.g., woodland or desert). However, in some instances, we use habitat and microhabitat synonymously to mean the actual substrate or perch on which an individual occurs. We feel our use of habitat in both these contexts is appropriate for our review because we believe that the general consequences of habitat (or microhabitat) use at any scale will be the same for a given species (i.e., certain requirements must be met for an individual or population to be successful).

\section{CONSEQUENCES OF HABITAT AND MICROHABITAT USE}

The consequences of living in a particular habitat can be manifested at several levels, ranging from effects on the individual to effects on an entire community. Below we discuss the implications of using different habitats for (1) individuals, (2) populations, and (3) communities.

Individuals

Being ectotherms means that lizards are affected by the thermal and biophysical environments that they experience. Ectotherm physiology and ecology are intimately linked (Huey and Stevenson, 1979) and so anything influencing physiology can affect performance or life histories (e.g., Congdon, 1989; Dunham et al., 1989; Porter, 1989). Different habitats often provide different biophysical environments (e.g., Bartlett and Gates, 1967; Pearson, 1977; Bakken, 1989; Bashey and Dunham, 1997). Indeed, lizards often choose habitats and microhabitats that facilitate thermoregulation or that allow them to maintain the appropriate body temperature (Table 1).

Different habitats can influence thermoregulatory behavior. For example, Anolis cristatellus in Puerto Rico actively thermoregulate when in open habitats, but passively thermoregulate in closed habitats (Huey, 1974; see also Gillis, 1991 for an example from Sceloporus undulatus). Some habitats (e.g., those with low transmittance of solar 
radiation) virtually eliminate the possibility for active thermoregulation by lizards, as in the case of the Australian forest dragon (Hypsilurus spinipes) (Rummery et al., 1994), the crevice-dwelling lizard, Xenosaurus newmanorum (Lemos-Espinal et al., 1998), and the lacertid lizards Podarcis melisellensis and $P$. muralis in the autumn (but not other times of the year) (Grbac and Bauwens, 2001). Kentropyx calcarata and Mabuya nigropunctata in lowland Amazonian tropical forest occur near opening or treefall clearings because they require sunlight to be able to maintain high body temperatures (Vitt et al., 1997).

Lizards inhabiting certain habitats providing a given biophysical environment can be expected to experience different internal environments than lizards in another habitat which could result in differences in physiological performances (see Huey, 1991), possibly resulting in differentiation of thermal preferences, physiology, and performance between individuals in different populations and habitat types (Garland and Adolph, 1991; Miles, 1994). Ultimately the habitat in which a lizard occurs can influence its energy budget (Bartlett and Gates, 1967; Congdon et al., 1982) since digestive efficiency and capacity are often influenced by body temperature (Harlow et al., 1976; Harwood, 1979; Troyer, 1987; Zimmerman and Tracy, 1989; van Marken Lichtenbelt, 1993), suggesting that lizards in different habitats may experience different digestive efficiencies. The metabolic rate of lizards in habitats with different thermal regimes can be different (e.g., Beaupre et al., 1993; Beyer and Spotila, 1994). Often metabolic rates increase with temperature (e.g., Christian et al., 1998; Mouton et al., 2000). Feeding rate and energy expenditure can also differ between habitats (Karasov and Anderson, 1984), as can other aspects of foraging behavior (e.g., capture rate; Bullock et al., 1993). In addition, temperature can affect other aspects of feeding behavior, such as foraging activity and handling time (Moermond, 1979a,b; Avery et al., 1982; Karasov and Anderson, 1984; DeQuieroz et al., 1987; Grant and Dunham, 1988; Avery and Mynott, 1990), as well as capture success (Díaz, 1994).

Lizard sprint speed and behavior are often significantly affected by body temperature (Rand, 1964b; Hertz et al., 1982, 1983; Mautz et al., 1992; Torr and Shine, 1993). Lowered sprint speeds conceivably influence susceptibility to predation (see Christian and Tracy, 1981). Habitat use, by its effects on body temperature, can generate habitat specific sprint speeds for lizards (e.g., Waldschmidt and Tracy, 1983), resulting in habitat specific predator escape ability; as well as habitat specific escape behavior. For example, during periods of the year when vegetation is sparse (e.g., early spring), Psammodromus algirus flee from the approach of a possible predator earlier than when vegetation is more dense (e.g., summer) (Martín and López, 1995a). Within a season, escape behavior by $P$. algirus is also dependent on the amount of vegetation present: in more open microhabitats flight distances are greater than in more vegetated microhabitats (Martín and López, 1995a,b; see also Martín and Lopez, 2000). Snell et al. (1988) got similar results in a study on Tropidurus albemarlensis in the Galápagos Islands. In three species of Anolis from Cuba, the habitat used affected escape strategies: anoles on trees with big trunks ran around to the other side of the trunk whereas anoles on trees with small trunks jumped to another tree or perch (Regalado, 1998). However, escape tactics are not always affected by habitat structure 
(e.g., Sceloporus virgatus; Smith, 1996a). In addition, lizard morphology can interact with habitat use to affect sprint speed and clinging ability (Losos and Sinervo, 1989; Losos et al., 1993b). For example, Irschick and Losos (1999) found that eight species of Anolis tend to use habitats whose structure (e.g., distribution of perch diameters) allows maximal performance (e.g., sprint speed).

Life histories in lizards are often influenced by the proximate environment (see Ballinger, 1983; Dunham et al., 1989). Habitat use can affect lizard life histories by determining the proximate environment (biotic or abiotic) experienced by the lizard. For example, the habitats and microhabitats used by lizards may differ in the amount of food available for consumption (e.g., Alberts, 1993; Hews, 1993; Durtsche, 1995; Vitt and de Carvalho, 1995; Vitt et al., 1996; Smith, 1998). In combination with the potential thermal differences between habitats outlined above, use of different habitats and microhabitats could easily affect the growth, reproduction, and survivorship of lizards (i.e., their life histories).

Several studies have demonstrated an effect of habitat use on the life history traits of lizards (see Table 2). Often the effects of habitat are due to differences in food availability or activity periods that can be affected by the habitat an individual is in. Along an elevational gradient populations of Sceloporus merriami experience different biophysical environments which determine activity regimes (Grant and Dunham, 1988; Grant, 1990). Podarcis torquatus, which occur in forest habitats in Chile, have longer activity periods than $P$. volcanensis, which occur in more open habitats (Labra and Rosenmann, 1992). The activity regime of a population can interact with the amount of food available to create life history differences between populations (Grant and Dunham, 1990; Niewiarowski and Roosenburg, 1993).

The habitat that a parent lizard uses, particularly a pregnant female (if viviparous) or an ovipositing female (if oviparous), can have consequences for the performance of their offspring (see Overall, 1994 for a detailed discussion). Many of these consequences arise from the thermal or hydric environments experienced by the pregnant female or the incubating eggs. In many species, cooler incubation sites lead to slower embryonic developmental rates than warmer incubation sites (e.g., Qualls and Andrews, 1999; Shine, 1999). Incubation conditions can also affect hatchling performance such as growth rate, sprint speed, and endurance (e.g., Qualls and Andrews, 1999; Shine, 1999). Sceloporus undulatus eggs incubated at different temperatures differed in tail length (shorter at cooler temperatures), SVL (shorter at cooler temperatures), growth rate of hatchlings in the laboratory (faster at cooler temperatures), $42 \mathrm{~d}$ and overwinter survival (higher at cooler temperatures) (Andrews et al., 2000). Hatchlings from Cyclura nubila eggs incubated at warmer temperatures were no different in size at hatching than eggs incubated at lower temperatures, but did grow faster during their first year (Alberts et al., 1997). In four species of Sceloporus (S. aeneus, S. scalaris, S. undulatus, S. virgatus), eggs incubated at a range of temperatures did not differ in mortality (except for a high elevation population of $S$. virgatus which showed higher mortality at low temperatures) but did show a delay in hatching at low incubation temperatures (Andrews et al., 1997). In addition to the effects on aspects of offspring performance 
(e.g., growth and survivorship), the physical characteristics of the habitat in which a female lizard lays her eggs can determine the sex of her offspring in some species (e.g., Agama agama, Charnier, 1966; Chlamydosaurus kingii, Harlow and Shine, 1999; Ctenophorus decresii and C. ornatus, Harlow, 2000; Eublepharis macularis, Viets et al., 1993).

Pregnant females often use their habitats in such a way as to maintain a body temperature that is different from those maintained by males or non-pregnant females (e.g., Garrick, 1974; Beuchat, 1986; Smith and Ballinger, 1994a,b; Mathies and Andrews, 1997; Rock et al., 2000). Such thermoregulation may influence embryonic development and neonate performance (e.g., Beuchat and Ellner, 1987; Beuchat, 1988; Shine and Harlow, 1993; Mathies and Andrews, 1997). Swain and Jones (2000) experimentally evaluated the effects of manipulating the opportunity for pregnant female Niveoscincus metallicus to thermoregulate (i.e., bask) on aspects of their reproduction and offspring performance. They found that females that could not bask as often gave birth less often, had a longer gestation period, and had smaller neonates that grew slower after birth as females that could bask without restrictions.

One of the things that becomes clear as one considers the studies above is that we have a fairly good understanding of how variations in the thermal environment affect individual lizard performance. It is also clear that we do not have a full understanding of how other aspects of a habitat or microhabitat (e.g., predation risk, food availability, water relations) affect individual performance, nor do we understand how these different aspects of a habitat or microhabitat interact to determine individual performance, let alone the consequences for lizard populations (see Populations). There is a definite need for additional studies to assess the relative importance of various habitat characteristics for individual performance in lizards.

\section{Populations}

While it is clear from the studies above that the physical and biotic characteristics of a habitat have ecological consequences for the performance of individual lizards, the impacts on lizard populations are often assumed to follow from the impacts on individual lizards. Unfortunately, there are few studies that have attempted to directly assess the link between the correspondence between habitat quality from the individual lizard's perspective and the performance of lizard populations in the same habitat. One exception is a study by Díaz (1997). He studied two populations of Psammodromus algirus, one at high elevation and one at low elevation. From a performance perspective (e.g., sprint speed, ability to thermoregulate), the low elevation site would be considered a higher quality habitat than the high elevation site. Interestingly, the abundance of lizards was significantly higher at the high elevation site, suggesting that simply measuring various aspects of individual performance in a habitat may not be sufficient to understand the consequences of habitat use on population performance and abundance. We need more studies like this to determine whether the consequences for individuals also necessarily have consequences for populations, or whether we can overestimate the importance of a single aspect of habitat use, such as thermal quality, 
while not considering other consequences such as predation risk, prey availability, as suggested by Díaz (1997).

There are several studies that assess the impact of habitat and microhabitat changes on lizard populations; however, the specific mechanisms causing the population changes are often poorly understood. The habitat used and preferred by lizards has definite consequences for the success of populations of lizards in the face of habitat changes. For example, lizards that use open habitats tend to be positively affected at a population level by livestock grazing whereas lizards that need vegetative cover tend to be negatively affected at a population level by livestock grazing (Table 3 ). Similarly, some lizard species (e.g., Urosaurus ornatus) are able to exploit residential areas along an urbanization gradient, whereas other lizards are only able to exploit the natural habitats (e.g., Cnemidophorus spp.) along the urbanization gradient (Germaine and Wakeling, 2001).

In some cases, habitat use may increase the possibility of a decline in a lizard population. For example, the common chameleon (Chamaeleo chamaeleon) in Spain often uses habitats that are closely associated with human activity, thus making them more susceptible to possible declines due to over collection, road related mortality, and agricultural practices (Hódar et al., 2000). Clearcutting has a strong negative effect in arboreal lizards and decreased total lizard biomass in a north Florida flatwood (Enge and Marion, 1986). In Argentina, a change in habitat structure due to road building changes a lizard assemblage due to loss of particular habitats (e.g., Spartina ciliata patches) used by some species but not others (Vega et al., 2000). Those that use that habitat decreased while those that did not use the habitat did not show changes in abundance (Vega et al., 2000). Rock collectors removing rocks from the environment of the velvet gecko, Oedura lesueurii, reduces the amount of habitat available for it to use (Schlesinger and Shine, 1994), thus possibly leading to a decline in velvet gecko abundance (Shine et al., 1998). The rocks appear to be important for thermoregulation by these geckos (Downes and Shine, 1998; Webb and Shine, 2000), which may affect gecko growth and survivorship (Webb and Shine, 2000).

In other cases, habitat use may facilitate population persistence in the face of human alterations of habitat. For example, Egernia major uses basking to maintain its body temperature and this is commonly found in more open or edge habitats and thus they may actually benefit from some human activities such as logging (Klingenböck et al., 2000). In French Guiana, one species of lizard, Kentropyx calcarata, becomes the most abundant and the dominant species on habitat islands created by flooding due to the creation of a hydroelectric dam reservoir, in part because of its generalist habitat use (Cosson et al., 1999). Timber practices in the Amazon, by altering the thermal and solar insolation properties of the habitat alter the make up of the lizard assemblage by increasing the number of heliothermic species in a particular area (Vitt et al., 1998a; Sartorius et al., 1999). Fire and other disturbances, such as clear-cutting timber, by maintaining a variety of successional stages of vegetation often associated with varying amounts of habitat structure and complexity allowing open habitat species and closed habitat species to persist, can be important influences on lizard distributions and 
abundances in many systems (e.g., mallee woodlands and heathlands of Australia, Friend, 1993; sand-pine scrub of Florida, Mushinsky, 1985; Greenberg et al., 1994).

\section{Communities}

Differential habitat use by two or more lizard species, whether the result of current ecological interactions or past ecological interactions that have led to evolutionary change (e.g., "ghost of competition past"), may permit coexistence of potential competitors thus affecting community structure and composition. Several authors have suggested that their observations of habitat segregation between lizard species indicate current or past competition. In several cases, experimental evidence is absent, and the conclusions are based upon supposition (Table 4). Clearly, the strongest evidence for the role of habitat use in allowing coexistence of potential competitors comes from experimental studies. Such studies do exist and the results of these experiments have found evidence for habitat use mediated coexistence or competition enforced habitat segregation in lizards (Table 5 ). On the other hand, many authors have used observational evidence and supposition to argue that habitat segregation is not reducing competition, but rather is serving another function (e.g., each species is filling its specific needs independently of the presence or absence of other species) (Table 4). Experimental evidence also sometimes supports the lack of competition's importance in habitat segregation (Table 5).

Predator-prey interactions can also be influenced by habitat use. Lizards may use habitats based upon the presence of predator refuges, and thus alter their predation risk by using particular habitats. Densities of adult Sceloporus jarrovii are dependent on the number of rocks present as well as the number of rock cracks which presumably provide predator refuges (Ruby, 1986). Trees with holes in them and surrounded by brush are preferred by Eumeces laticeps because the holes, in addition to serving a role in nesting, may act as predator refuges (Cooper, 1993; Cooper and Vitt, 1994). In Chile, two species of Liolaemus (L. platei and L. nigromaculatus) partition rock and ground habitats, with $L$. platei on the ground and L. nigromaculatus on rocks (Fuentes and Cancino, 1979). Both morphology and behavior suggest partitioning is based on predation. Liolaemus platei has both anti-predator behavior and morphology whereas $L$. nigromaculatus does not. In this situation, it actually appears that predation and competition interact to influence the observed habitat use in these two lizards: predation limits $L$. nigromaculatus to the rocks while competition from $L$. nigromaculatus excludes L. platei from the rocks. Anolis stratulus (Reagan, 1992) and Anolis cristatellus (Chandler and Tolson, 1990) use smaller perches presumably because their predators (two larger species of Anolis, and Epicrates monensis, respectively) are unable to use the smaller perches. Other anoles have been shown to alter their perch heights in response to the introduction of rats (Campbell, 1989 cited in Chandler and Tolson, 1990). The use of lower and narrower perches by juvenile Anolis lineatopus and $A$. gundlachi may alter the ability of juveniles to detect predators, and thereby alter predation risk compared to other perches (Irschick et al., 2000). Ctenosaura hemolopha preferentially select perches on cacti with holes that presumably serve as predator refugia (Blázquez and Rodríguez-Estrella, 1997). Pygmy 
blue tongue lizards, Tiliqua adelaidensis, select deep, narrow burrows that increase their ability to protect against predators (Milne and Bull, 2000). Bauwens et al. (1999) suggest that the exclusive use of Euphorbia caput-medusae plants may in part reflect the possible decrease in predation risk these plants provide due to the number of potential shelters found in these plants. Martín and López (1998) argued that a seasonal shift in habitat use by Psammodromus algirus occurs to allow the lizards to exploit those habitats that provide the most protection from predators: In the spring, lizards avoid shrubs that have lost their leaves and use shrubs that retain their leaves, however, in the summer the lizards prefer to use the shrubs that had lost their leaves in the spring but now have leaves relative to the shrub that keeps its leaves throughout the year. Velvet geckos (Oedura lesueurii) use experimental rock refuges in such a way as to avoid scent cues of predatory snakes (Downes and Shine, 1998).

While the logic of the conclusions made in many of these studies appears to be valid, few studies have actually estimated predation risk or differences in predation risk in different habitats. Tail break frequency can often serve as a rough estimate of predation risk, and so by looking for differences in tail break frequency between lizards using different habitats may give us information on whether the habitat used by a lizard affects predation risk. Among Liolaemus lizards, species that tended to use perches that reduced their visibility to predators had lower tail break frequencies than species using perches that increased their visibility to predators (Jaksic and Fuentes, 1980). Elevational differences in tail break frequency between high and low elevation populations of Sceloporus jarrovii may arise through differences in the amount of vegetative cover and complexity (e.g., more tail loss in more open habitats) (Brown and Ruby, 1977). Parker (1994) also found that Sceloporus undulatus in more open habitats had higher tail break frequencies than those in more closed habitats. However, Smith (1996b) found that tail break frequencies did not differ between a wooded habitat and an open habitat in a population of Sceloporus virgatus.

One might also expect habitat use to affect parasite-host interactions. The evidence for an impact of habitat use on ectoparasite loads is variable. In some cases, such as Sceloporus occidentalis (Tälleklint-Eisen and Eisen, 1999), mite loads vary between different habitats. However, in other cases (e.g., Sceloporus virgatus, Smith, 1996c), mite loads do not vary between different habitats. Endoparasites (e.g., malaria) have also been shown to differ among sites, often because of the thermal or humidity properties of the habitat that may affect both the parasite and their vectors (e.g., Ayala and Spain, 1976; Rand et al., 1983; Schall, 1992; Schall and Marghoob, 1995; Staats and Schall, 1996; Schall et al., 2000); however, detailed studies on the effects of habitat on the distribution and effect of endoparasites are unfortunately lacking. Little else is known about the impact of habitat on parasite loads in lizards.

\section{CONCLUSIONS}

It is quite apparent from the studies reviewed above that habitat (and microhabitat) use has the potential to be of great importance for individual lizards, populations of lizards, and communities of lizards. At the individual level, the thermal properties of an 
environment have a major influence on performance, and in many cases, may be the most important factor in determining the consequences of using a particular habitat. Unfortunately we know fairly little about how other characteristics of habitat (e.g., structure, predation risk, food availability, etc.) influence individual performance. We definitely need more studies investigating the consequences of these other habitat characteristics on individual performance. At the population level, the studies reviewed above suggest that how lizards use their environment can influence their persistence in the face of changes in the structure of their habitat, but we actually have little information on the actual mechanisms behind the relationship between habitat use and population dynamics. We need more such studies, and more studies looking for the links between consequences at the individual and population level. In many cases, the mechanistic explanations are assumed, but not investigated. The results may not be what we expect (see discussion of Díaz, 1997 in the Population section). Finally, at the community level, it is clear that habitat use can often either be a consequence of competition (past or present) or be a mechanism of coexistence. Unfortunately, many studies draw conclusions on the role of habitat use mediating community structure without experimental evidence, and just as with populations, conclusions are drawn based on observations that are consistent with certain hypotheses (but actually are consistent with alternative hypotheses as well). Basically, it is time to start moving from studies describing habitat use and its consequences (such studies form the basis of further investigations, and as such should not be abandoned entirely, rather they should be used to focus future research), to studies investigating the specific mechanisms by which habitat use causes the effects on lizards that we see in nature.

\section{ACKNOWLEDGMENTS}

We thank M. Angilletta, J. Rettig, and two anonymous reviewers for comments on an earlier version of this manuscript.

\section{LITERATURE CITED}

ALBERTS, A.C.

1993. Relationship of space use to population density in an herbivorous lizard. Herpetologica 49: 469-479.

, A.M. PERRY, J.M. LEMM, AND J.A. PHILLIPS.

1997. Effects of incubation temperature and water potential on growth and thermoregulatory behavior of hatchling Cuban rock iguanas (Cyclura nubila). Copeia 1997: 766-776.

ANDREWS, R.M., T. MATHIES, AND D.A. WARNER.

2000. Effect of incubation temperature on morphology, growth, and survival of juvenile Sceloporus undulatus. Herpetological Monographs 14: 420-431.

, C.P. QUALLS, AND B.R. ROSE. 
1997. Effects of low temperature on embryonic development of Sceloporus lizards. Copeia 1997: 827-833.

AVERY, R.A., J.D. BEDFORD, AND C.P. NEWCOMBE. 1982. The role of thermoregulation in lizard biology: predatory efficiency in a temperate diurnal basker. Behavioral Ecology and Sociobiology 11: 261-267.

AND A. MYNOTT.

1990. The effects of temperature on prey handling time in the common lizard, Lacerta vivipara. Amphibia-Reptilia 11:111-122.

AYALA, S.C., AND R.M. SPAIN. 1976. A population of Plasmodium colombiense sp. $\mathrm{n}$. in the iguanid lizard, Anolis auratus. Journal of Parasitology 62: 177-189.

BAKKEN, G.S. 1989. Arboreal perch properties and the operative temperature experienced by small animals. Ecology 70: 922-930.

BALLINGER, R.E.

1983. Life history variations. Pages 241-260 in Lizard Ecology: Studies of a Model Organism (R.B. Huey, E.R. Pianka, and T.W. Schoener, eds). Harvard Univ. Press, Cambridge, Massachusetts.

AND J.D. CONGDON.

1996. Status of the bunch grass lizard, Sceloporus scalaris, in the Chiricahua Mountains of southeastern Arizona. Bulletin of the Maryland Herpetological Society 32: 67-69.

AND S.M. JONES.

1985. Ecological disturbance in a sandhills prairie: impact and importance to the lizard community on Arapaho Prairie in western Nebraska. Prairie Naturalist 17: 91-100.

\section{, AND J.W. NIETFELDT.}

1990. Patterns of resource use in a lizard community in the Nebraska sandhills prairie. Prairie Naturalist 22: 75-86.

AND K.S. WATTS.

1995. Path to extinction: impact of vegetational change on lizard populations on Arapaho Prairie in the Nebraska Sandhills. American Midland Naturalist 134: 413-417.

BARBAULT, R. 
1991. Ecological constraints and community dynamics: linking community patterns to organismal ecology. The case of tropical herpetofaunas. Acta Oecologica 12: 139-163.

AND M.-E. MAURY.

1981. Ecological organization of a Chihuahuan Desert lizard community. Oecologia 51: 335-342.

A. ORTEGA, AND M.-E. MAURY.

1985. Food partitioning and community organization in a mountain lizard guild of northern Mexico. Oecologia 65: 550-554.

BARTLETT, P.N. AND D.M. GATES.

1967. The energy budget of a lizard on a tree trunk. Ecology 48: 315-322.

BASHEY, F., AND A.E. DUNHAM.

1997. Elevational variation in the thermal constraints and microhabitat preferences of the greater earless lizard Cophosaurus texanus. Copeia 1997: 725-737.

BAUWENS, D., A.M. CASTILLA, AND P. LE F.N. MOUTON. 1999. Field body temperature, activity levels and opportunities for thermoregulation in an extreme microhabitat specialist, the girdled lizard (Cordylus macropholis). Journal of Zoology 249: 11-18.

BEAUPRE, S.J., A.E. DUNHAM, AND K.L. OVERALL. 1993. Metabolism of a desert lizard: the effects of mass, sex, population of origin, temperature, time of day, and feeding on oxygen consumption of Sceloporus merriami. Physiological Zoology 66: 128-147.

BEUCHAT, C.A. 1986. Reproductive influences on the thermoregulatory behavior of a livebearing lizard. Copeia 1986: 971-979.

1988. Temperature effects during gestation in a viviparous lizard. Journal of Thermal Biology 13: 135-142.

AND S. ELLNER.

1987. A quantitative test of life history theory: thermoregulation by a viviparous lizard. Ecological Monographs 57: 45-60.

BEYER, E.C., AND J.R. SPOTILA. 1994. Seasonal variation in metabolic rates and maintenance costs of the eastern fence lizard, Sceloporus undulatus. Comparative Biochemistry and Physiology 109A: 1039-1047.

BLÁZQUEZ, M.C. AND R. RODRÍGUEZ-ESTRELLA. 
1997. Factors influencing the selection of basking perches on Cardon cacti by spiny-tailed iguanas (Ctenosaura hemilopha). Biotropica 29: 344-348.

BOCK, C.E., H.M. SMITH, AND J.H. BOCK. 1990. The effect of livestock grazing upon abundance of the lizard, Sceloporus scalaris, in southeastern Arizona. Journal of Herpetology 24: 445-446.

BOUDJEMADI, K., J. LECOMTE, AND J. CLOBERT. 1999. Influence of connectivity on demography and dispersal in two contrasting habitats: an experimental approach. Journal of Animal Ecology 68: 1207-1224.

BROOKS, M. 1999. Effects of protective fencing on birds, lizards, and black-tailed hares in the Western Mojave Desert. Environmental Management 23: 387-400.

BROWN, C.K., AND D.E. RUBY. 1977. Sex-associated variation in the frequencies of tail autotomy in Sceloporus jarrovi (Sauria: Iguanidae) at different elevations. Herpetologica 33: 380-387.

BULLOCK, D.J., H.M. JURY, AND P.G.H. EVANS. 1993. Foraging ecology in the lizard Anolis oculatus (Iguanidae) from Dominica, West Indies. Journal of Zoology 230: 19-30.

CAMPBELL, E.W. III. 1989. The impact of introduced rats on the vertebrate fauna of Antillean cays. M.S. Thesis, Bowling Green State University, Bowling Green, Ohio.

CASTILLA, A.M. AND D. BAUWENS. 1991. Thermal biology, microhabitat selection, and conservation of the insular lizard Podarcis hispanica atrata. Oecologia 85: 366-374.

CHANDLER, C.R. AND P.J. TOLSON. 1990. Habitat use by a boid snake, Epicrates monensis, and its anoline prey, Anolis cristatellus. Journal of Herpetology 24: 151-157.

CHARNIER, M. 1966. Action de la température sur la sex-ratio chez l'embryon d'Agama agama (Agamidae, Lacertilien). Comtes Rendus des Séances de la Societe de Biologie et des ses Filiales 160: 620-622.

CHRISTIAN, K.A., G. BEDFORD, B. GREEN, T. SCHULTZ, AND K. NEWGRAIN. 1998. Energetics and water flux of the marbled velvet gecko (Oedura marmorata) in tropical and temperate habitats. Oecologia 116: 336-342. 


\section{AND C.R. TRACY.}

1981. The effect of thermal environment on the ability of hatchling Galapagos land iguanas to avoid predation during dispersal. Oecologia 49: 218-223. 1985. Physical and biotic determinants of space utilization by the Galapagos land iguana (Conolophus pallidus). Oecologia 66: 132-140.

, AND W.P. PORTER.

1983. Seasonal shifts in body temperature and use of microhabitats by Galapagos land iguanas (Conolophus pallidus). Ecology 64: 463-468. 1984. Physiological and ecological consequences of sleeping-site selection by the Galapagos land iguana (Conolophus pallidus). Ecology 65: 752-758.

CIVANTOS, E.

2000. Home-range ecology, aggressive behaviour, and survival in juvenile lizards, Psammodromus algirus. Canadian Journal of Zoology 78: 1681-1685.

AND A. FORSMAN.

2000. Determinants of survival in juvenile Psammodromus algirus lizards.

Oecologia 124: 64-72.

, A. SALVADOR, AND J.P. VEIGA.

1999. Body size and microhabitat affect winter survival of

hatchling Psammodromus algirus lizards. Copeia 1999: 1112-1117.

CONGDON, J.D.

1989. Proximate and evolutionary constraints on energy relations of

reptiles. Physiological Zoology 62: 356-373.

, L.J. VITT, R.C. VAN LOBEN SELS, AND R.D. OHMART.

1982. The ecological significance of water flux rates in arboreal desert lizards of the genus Urosaurus. Physiological Zoology 55: 317-322.

COOPER, W.E. JR.

1993. Tree selection by the broad-headed skink, Eumeces laticeps: size, holes, and cover. Amphibia-Reptilia 14: 285-294.

AND L.J. VITT.

1994. Tree and substrate selection in the semi-arboreal lizard Eumeces laticeps. Herpetological Journal 4: 20-23.

COSSON, J.F., S. RINGUET, O. CLAESSENS, J.C. DE MASSARY, A. DALECKY, J.F. VILLIERS, L.

GRANJON, AND J.M. PONS.

1999. Ecological changes in recent land-bridge islands in French Guiana, with

emphasis on vertebrate communities. Biological Conservation 91: 213-222. 
DAVIS, J. AND N.A.M. VERBEEK.

1972. Habitat preferences and the distribution of Uta stansburiana and Sceloporus occidentalis in coastal California. Copeia 1972: 643-649.

DEQUEIROZ, A., F.H. POUGH, R.M. ANDREWS, AND A. COLLAZO. 1987. Thermal dependence of prey-handling costs for the scincid lizard, Chalcides ocellatus. Physiological Zoology 60: 492-498.

DÍAZ, J.

1992. Choice of compass directions around shrub patches by the heliothermic lizard Psammdromus algirus. Herpetologica 48: 293-300.

1994. Effects of body temperature on the predatory behaviour of the lizard Psammodromus algirus hunting winged and wingless prey. Herpetological Journal 4: 145-150.

1997. Ecological correlates of the thermal quality of an ectotherm's habitat: a comparison between two temperate lizard populations. Functional Ecology 11: 79-89.

\section{R. DÍAZ-URIARTE, AND A. RODRÍGUEZ.} 1996. Influence of behavioral thermoregulation on the use of vertical surfaces by Iberian wall lizards Podarcis hispanica. Journal of Herpetology 30: 548-552.

DOWNES, S. AND R. SHINE. 1998. Heat, safety, or solitude? Using habitat selection experiments to identify a lizard's priorities. Animal Behaviour 55: 1387-1396.

DUNHAM, A.E.

1983. Realized niche overlap, resource abundance, and intensity of interspecific competition. Pages 261-280 in Lizard Ecology: Studies of a Model Organism (R.B. Huey, E.R. Pianka, and T.W. Schoener, eds). Harvard Univ. Press, Cambridge, Massachusetts.

, B.W. GRANT, AND K.L. OVERALL.

1989. Interfaces between biophysical and physiological ecology and the population ecology of terrestrial vertebrate ectotherms. Physiological Zoology 62: 335-355.

\section{DURTSCHE, R.D.}

1995. Foraging ecology of the fringe-toed lizard, Uma inornata, during periods of high and low food abundance. Copeia 1995: 915-926.

AND S.C.

P.J. GIER, M.M. FULLER, W.I. LUTTERSCHMIDT, R. BRADLEY, C.K. MEIER, HARDY. 
1997. Ontogenetic variation in the autecology of the greater earless lizard Cophosaurus texanus. Ecography 20: 336-346.

ENGE, K.M. AND W.R. MARION. 1986. Effects of clearcutting and site preparation on herpetofauna of a north Florida flatwoods. Forest Ecology and Management 14: 177-192.

FAIR, W.S., AND S.E. HENKE.

1997. Effects of habitat manipulation on Texas horned lizards and their prey. Journal of Wildlife Management 61: 1366-1370.

FOX, S.F., E. ROSE, AND R. MYERS.

1981. Dominance and the acquisition of superior home ranges in the lizard Uta stansburiana. Ecology 62: 888-893.

FRIEND, G.R.

1993. Impact of fire on small vertebrates in Mallee woodlands and heathlands of temperate Australia: a review. Biological Conservation 65: 99-114.

FUENTES, E.R., AND J. CANCINO.

1979. Rock-ground patchiness in a simple Liolaemus lizard community (Reptilia, Lacertilia, Iguanidae). Journal of Herpetology 13: 343-350.

GANNON, M.R. AND K.B. WILLIS.

1990. Clutch size and parasitism of the Texas spotted whiptail, Cnemidophorus gularis (Sauria: Teiidae), from south-central Texas. Southwestern Naturalist 35: 215- 217.

GANS, C., AND R.B. HUEY, EDS. 1988. Biology of the Reptilia, Vol. 16 Ecology B: Defense and Life History. Alan R. Liss, New York.

, AND F.H. POUGH, EDS.

1982a. Biology of the Reptilia, Vol. 12 Physiology C: Physiological Ecology. Academic Press, London.

1982b. Biology of the Reptilia, Vol. 13 Physiology D: Physiological Ecology. Academic Press, London.

GARLAND, T. JR. AND S.C. ADOLPH. 1991. Physiological differentiation of vertebrate populations. Annual Review of Ecology and Systematics 22: 193-223.

GARRICK, L.D.

1974. Reproductive influences on behavioral thermoregulation in the lizard, Sceloporus cyanogenys. Physiology and Behavior 12: 85-91. 
GERMAINE, S.S., AND B.F. WAKELING.

2001. Lizard species distributions and habitat occupation along an urban gradient in Tucson, Arizona, USA. Biological Conservation 97: 229-237.

GERMANO, D.J. AND C.R. HUNGERFORD.

1981. Reptile population changes with manipulation of Sonoran Desert shrub. Great Basin Naturalist 41: 129-138.

GILLIS, R.

1991. Thermal biology of two populations of red-chinned lizards (Sceloporus undulatus erythrocheilus) living in different habitats in southcentral Colorado. Journal of Herpetology 25: 18-23.

GRANT, B.W.

1990. Trade-offs in activity time and physiological performance for themoregulating desert lizards, Sceloporus merriami. Ecology 71: 2323-2333.

AND A.E. DUNHAM.

1988. Thermally imposed time constraints on the activity of the desert

lizard Sceloporus merriami. Ecology 69: 167-176.

1990. Elevational covariation in environmental constraints and life histories of the desert lizard Sceloporus merriami. Ecology 71: 1765-1776.

GRBAC, I., AND D. BAUWENS.

2001. Constraints on temperature regulation in two sympatric Podarcis lizards during autumn. Copeia 2001: 178-186.

GREENBERG, C.H., D.G. NEARY, AND R.D. HARRIS. 1994. Effect of high-intensity wildfire and silvicultural treatments on reptile communities in sand-pine scrub. Conservation Biology 8: 1047-1057.

HARLOW, H.J., S.S. HILLMAN, AND M. HOFFMAN.

1976. The effect of temperature on digestive efficiency in the herbivorous lizard, Dipsosaurus dorsalis. Journal of Comparative Physiology 111B: 1-6.

HARLOW, P.S.

2000. Incubation temperature determines hatchling sex in Australian rock dragons (Agamidae: genus Ctenophorus). Copeia 2000: 958-964.

AND R. SHINE.

1999. Temperature-dependent sex determination in the frillneck

lizard, Chlamydosaurus kingii (Agamidae). Herpetologica 55: 205-212.

HARWOOD, R.H. 
1979. The effect of temperature on the digestive efficiency of three species of lizards, Cnemidophorus tigris, Gerrhonotus multicarinatus and Sceloporus occidentalis. Comparative Biochemistry and Physiology 63A: 417-433.

HEATWOLE, $\mathrm{H}$.

1977. Habitat selection in reptiles. Pages 137-155 in Biology of the Reptilia, Vol. 7: Ecology and Behavior (C. Gans and D.W. Tinkle, eds). Academic Press, New York, New York.

HERTZ, P.E., R.B. HUEY, AND E. NEVO. 1982. Fight versus flight: body temperature influences defensive responses of lizards. Animal Behaviour 30: 676-679. 1983. Homage to Santa Anita: thermal sensitivity of sprint speed in agamid lizards. Evolution 37: 1075-1084.

HEWS, D.K.

1993. Food resources affect female distribution and male mating opportunities in the iguanian lizard Uta palmeri. Animal Behaviour 46: 279-291.

HÓDAR, J.A., J.M. PLEGUEZUELOS, AND J.C. POVEDA. 2000. Habitat selection of the common chameleon (Chamaeleo chamaeleon) (L.) in an area under development in southern Spain: implications for conservation. Biological Conservation 94: 63-68.

HOLT, R.D. 1987. Population dynamics and evolutionary processes: the manifold roles of habitat selection. Evolutionary Ecology 1: 331-347.

HOWARD, K.E. AND A. HAILEY.

1999. Microhabitat separation among diurnal saxicolous lizards in Zimbabwe. Journal of Tropical Ecology 15: 367-378.

HUEY, R.B.

1974. Behavioral thermoregulation in lizards: importance of associated costs. Science 184: 1001-1003. 1991. Physiological consequences of habitat selection. American Naturalist 137: S91- S115.

, E.R. PIANKA, M.E. EGAN, AND L.W. COONS. 1974. Ecological shifts in sympatry: Kalahari fossorial lizards (Typhlosaurus). Ecology 55: 304-316.

AND T.W. SCHOENER, EDS. 1983. Lizard Ecology: Studies of a Model Organism. Harvard University Press, Cambridge, Mass. 
AND R.D. STEVENSON.

1979. Integrating thermal physiology and ecology of ectotherms: a discussion of approaches. American Zoologist 19: 357-366.

IRSCHICK, D.J. AND J.B. LOSOS.

1999. Do lizards avoid habitats in which performance is submaximal? The relationship between sprinting capabilities and structural habitat use in Caribbean anoles. American Naturalist 154: 293-305.

, T.E. MACRINI, S. KORUBA, AND J. FORMAN. 2000. Ontogenetic differences in morphology, habitat use, behavior, and sprinting capacity in two West Indian Anolis lizards. Journal of Herpetology 34: 444-451.

JAKSIC, F.M. AND E.R. FUENTES. 1980. Correlates of tail losses in twelve species of Liolaemus lizards. Journal of Herpetology 14: 137-141.

JENSSEN, T.A.

1973. Shift in the structural habitat of Anolis opalinus due to congeneric competition. Ecology 54: 863-869.

, D.L. MARCELLINI, C.A. PAGUE, AND L.A. JENSSEN. 1984. Competitive interference between the Puerto Rican lizards, Anolis cooki and A. cristatellus. Copeia 1984: 853-862.

JONES, K.B. 1981. Effects of grazing on lizard abundance and diversity in western Arizona. Southwestern Naturalist 26: 107-115.

KARASOV, W.H. AND R.A. ANDERSON.

1984. Interhabitat differences in energy acquisition and expenditure in a lizard. Ecology 65: 235-247.

KLINGENBÖCK, A., K. OSTERWALDER, AND R. SHINE. 2000. Habitat use and thermal biology of the "land mullet" Egernia major, a large Scincid lizard from remnant rain forest in southeastern Australia. Copeia 2000: 931- 939.

\section{LABRA, A.AND M. ROSENMANN.} 1992. Comparative diel activity of Pristidactylus lizards from forest and scrubland habitats. Journal of Herpetology 26: 501-503.

LEAL, M., J.A. RODRÍGUEZ-ROBLES, AND J.B. LOSOS. 1998. An experimental study of interspecific interactions between two Puerto Rican Anolis species. Oecologia 117: 273-278. 
LEMOS-ESPINAL, J.A., G.R. SMITH, AND R.E. BALLINGER.

1998. Thermal ecology of the crevice-dwelling lizard, Xenosaurus newmanorum. Journal of Herpetology 32: 141-144.

LISTER, B.C.

1976. The nature of niche expansion in West Indian Anolis lizards I: ecological consequences of reduced competition. Evolution 30: 659-676.

LORENZON, P., J. CLOBERT, A. OPPLIGER, AND H. JOHN-ALDER. 1999. Effect of water constraint on growth rate, activity and body temperature of yearling common lizard (Lacerta vivipara). Oecologia 118: 423-430.

LOSOS, J.B., J.C. MARKS, AND T.W. SCHOENER.

1993a. Habitat use and ecological interactions of an introduced and a native species of Anolis lizard on Grand Cayman, with a review of the outcomes of anole introductions. Oecologia 95: 525-532.

AND B. SINERVO.

1989. The effects of morphology and perch diameter on sprint performance of Anolis lizards. Journal of Experimental Biology 145: 23-30.

, B.M. WALTON, AND A.F. BENNETT.

1993b. Trade-offs between sprinting and clinging ability in Kenyan chameleons. Functional Ecology 7: 281-286.

MARCELLINI, D. AND J.P. MACKEY. 1970. Habitat preferences of the lizards, Sceloporus occidentalis and $S$. graciosus (Lacertilia, Iguanidae). Herpetologica 26: 51-56.

MARKEN LICHTENBELT, W.D. VAN. 1993. Digestion in an ectothermic herbivore, the green iguana (Iguana iguana): effect of food composition and body temperature. Physiological Zoology 65: 649673.

MARTÍN, J. AND P. LÓPEZ.

1995a. Influence of habitat structure on the escape tactics of the lizard Psammodromus algirus. Canadian Journal of Zoology 73: 129-132. 1995b. Escape behaviour of juvenile Psammodromus algirus lizards: constraint of or compensation for limitations in body size?. Behaviour 132: 181-192. 1998. Shifts in microhabitat use by the lizard Psammodromus algirus: responses to seasonal changes in vegetation structure. Copeia 1998: 780-786. 2000. Fleeing to unsafe refuges: Effects of conspicuousness and refuge safety on the escape decisions of the lizard Psammodromus algirus. Canadian Journal of Zoology 78: 265-270. 
, L.M. CARRASCAL, AND A. SALVADOR.

1995. Adjustment of basking postures in the high-altitude lberian rock lizard (Lacerta monticola). Canadian Journal of Zoology 73: 1065-1068.

MARTÍN-VALLEJO, J., J. GARCÍA-FERNÁNDEZ, V. PÉREZ-MELLADO, AND J. VICENTE-

VILLARDÓN.

1995. Habitat selection and thermal ecology of the sympatric lizards Podarcis muralis and Podarcis hispanica in a mountain region of central Spain.

Herpetological Journal 5: 181-188.

MATHIES, T., AND R.M. ANDREWS. 1997. Influence of pregnancy on the thermal biology of the lizard, Sceloporus jarrovi: why do pregnant females exhibit low body temperatures?. Functional Ecology 11: 498-507.

MAUTZ, W.J., C.B. DANIELS, AND A.F. BENNETT. 1992. Thermal dependence of locomotion and aggression in a Xantusiid lizard. Herpetologica 48: 271-279.

MEDEL, R.G., P.A. MARQUET, AND F.M. JAKSIC. 1988. Microhabitat shifts of lizards under different contexts of sympatry: a case study with South American Liolaemus. Oecologia 76: 567-569.

MIDDENDORF, G.A. AND C.A. SIMON. 1988. Thermoregulation in the iguanid lizard Sceloporus jarrovi: The influence of age, time, and light condition on body temperature and thermoregulatory behaviors. Southwestern Naturalist 33: 347-356.

MILES, D.B.

1994. Population differentiation in locomotor performance and the potential response of a terrestrial organism to global environmental change. American Zoologist 34: 422- 436.

MILNE, T. AND C.M. BULL. 2000. Burrow choice by individuals of different sizes in the endangered pygmy blue tongue lizard Tiliqua adelaidensis. Biological Conservation 95: 295-301.

MILSTEAD, W.W., ED. 1967. Lizard Ecology: A Symposium. University of Missouri Press, Columbia.

MOERMOND, T.C.

1979a. Habitat constraints on the behavior, morphology, and community structure of Anolis lizards. Ecology 60: 152-164. $1979 \mathrm{~b}$. The influence of habitat structure on Anolis foraging behavior. Behaviour 70: 147-167. 
MORRIS, D.W.

1987a. Ecological scale and habitat use. Ecology 68: 362-369.

1987b. Spatial scale and the cost of density-dependent habitat selection.

Evolutionary Ecology 1: 379-388.

1988. Habitat-dependent population regulation and community structure.

Evolutionary Ecology 2: 253-269.

1992. Scales and costs of habitat selection in heterogeneous landscapes.

Evolutionary Ecology 6: 412-432.

MOUTON, P. LE F.N., D. FOURIE, AND A.F. FLEMMING.

2000. Oxygen consumption in two cordylid lizards, Cordylus

cataphractus and Cordylus polyzonus. Amphibia-Reptilia 21: 502-507.

MUSHINSKY, H.R.

1985. Fire and the Florida sandhill herpetofaunal community: with special attention to responses of Cnemidophorus sexlineatus. Herpetologica 41: 333342.

NIEWIAROWSKI, P.H. AND W. ROOSENBURG. 1993. Reciprocal transplant reveals sources of variation in growth rates of the lizard Sceloporus undulatus. Ecology 74: 1992-2002.

ORTEGA, A., M.-E. MAURY, AND R. BARBAULT. 1982. Spatial organization and habitat partitioning in a mountain lizard community of Mexico. Acta Oecologica 3: 323-330.

ORTIZ, P.R. AND T.A. JENSSEN. 1982. Interspecific aggression between lizard competitors, Anolis cooki and Anolis cristatellus. Zeitschrift für Tierpsychologie 60: 227-238.

OVERALL, K.L. 1994. Lizard egg environments. Pages 51-72 in Lizard Ecology: Historical and Experimental Perspectives (L.J. Vitt, and E.R. Pianka, eds). Princeton Univ. Press, Princeton, New Jersey.

PACALA, S. AND J. ROUGHGARDEN. 1982. Resource partitioning and interspecific competition in two two-species insular Anolis lizard communities. Science 217: 444-446.

1985. Population experiments with the Anolis lizards of St. Maarten and St. Eustatius. Ecology 66: 129-141.

PARKER, W.S. 1994. Demography of the fence lizard, Sceloporus undulatus, in northern Mississippi. Copeia 1994: 136-152. 
PATTERSON, G.B.

1992. The ecology of a New Zealand grassland lizard guild. Journal of the Royal Society of New Zealand 22: 91-106.

PAULISSEN, M.A.

1988. Ontogenetic and seasonal shifts in microhabitat use by the lizard Cnemidophorus sexlineatus. Copeia 1988: 1021-1029.

PEARSON, O.P.

1977. The effect of substrate and of skin color on thermoregulation of a lizard. Comparative Biochemistry and Physiolology 58A: 353-358.

PETREN, K. AND T.J. CASE.

1998. Habitat structure determines competition intensity and invasion success in gecko lizards. Proceedings of the National Academy of Science 95: 1173911744.

PORTER, W.P. 1989. New animal models and experiments for calculating growth potential at different elevations. Physiological Zoology 62: 286-313.

PULLIAM, H.R. AND B.J. DANIELSON.

1991. Sources, sinks, and habitat selection: a landscape perspective on population dynamics. American Naturalist 137: S50-S66.

QUALLS, C.P. AND R.M. ANDREWS. 1999. Cold climates and the evolution of viviparity in reptiles: cold incubation temperatures produce poor-quality offspring in the lizard, Sceloporus virgatus. Biological Journal of the Linnean Society 67: 353-376.

RAMÍREZ-BAUTISTA, A. AND M. BENABIB. 2001. Perch height of the arboreal lizard Anolis nebulosus (Sauria: Polychrotidae) from a tropical dry forest of México: Effect of the reproductive season. Copeia 2001: 187-193.

RAND, A.S. 1964a. Ecological distribution in anoline lizards of Puerto Rico. Ecology 45: 745752.

1964b. Inverse relationship between temperature and shyness in the lizard Anolis lineatopus. Ecology 45: 864-865.

, S. GUERRERO, AND R.M. ANDREWS.

1983. The ecological effects of malaria on populations of the lizard Anolis limifrons on Barro Carolina Island, Panama. Pages 455-471. in Advances in Herpetology and Evolutionary Biology (A.G.J. Rhodin and K. Miyata, eds). Museum of Comparative Zoology, Cambridge, Massachussetts. 


\section{AND S.S. HUMPHREY.}

1968. Interspecific competition in the tropical rain forest: ecological distribution among lizards at Belem, Para. Proceedings of the United States National Museum 125: 1-17.

REAGAN, D.P. 1992. Congeneric species distribution and abundance in a three-dimensional habitat: the rain forest anoles of Puerto Rico. Copeia 1992: 392-403.

REGALADO, R. 1998. Approach distance and escape behavior of three species of Cuban Anolis (Squamata, Polychrotidae). Caribbean Journal of Science 34: 211217.

ROCK, J., R.M. ANDREWS, AND A. CREE. 2000. Effects of reproductive condition, season, and site on selected temperatures of viviparous gecko. Physiological and Biochemical Zoology 73: 344-355.

ROMERO-SCHMIDT, H.L. AND A. ORTEGA-RUBIO. 1999. Changes in lizard abundance on protected versus grazed desert scrub in Baja California Sur, Mexico. Brazilian Archives of Biology and Technology 42: 175-180.

ROSE, B.R. 1976. Habitat and prey selection of Sceloporus occidentalis and Sceloporus graciosus. Ecology 57: 531-541.

ROSENZWEIG, M.L. 1991. Habitat selection and population interactions: the search for mechanism. American Naturalist 137: S5-S28.

RUBY, D.E.

1986. Selection of home range site by females of the lizard, Sceloporus jarrovi. Journal of Herpetology 20: 466-469.

RUMMEL, J.D. AND J. ROUGHGARDEN. 1985. Effects of reduced perch-height separation on competition between two Anolis lizards. Ecology 66: 430-444.

RUMMERY, C., R. SHINE, D.C. HOUSTON, AND M.B. THOMPSON. 1994. Thermal biology of the Australian forest dragon, Hypsilurus spinipes (Agamidae). Copeia 1995: 818-827.

SARTORIUS, S.S., L.J. VITT, AND G.R. COLLI. 
1999. Use of naturally and antropogenically disturbed habitats in Amazonian rainforest by the teiid lizard Ameiva ameiva. Biological Conservation 90: 91-101.

SCHALL, J.J.

1992. Parasite-mediated competition in Anolis lizards. Oecologia 92: 58-64.

AND A.B. MARGHOOB.

1995. Prevalence of a malarial parasite over time and space: Plasmodium

mexicanum in its vertebrate host, the western fence lizard Sceloporus

occidentalis. Journal of Animal Ecology 64: 177-185.

, H.R. PRENDEVILLE, AND K.A. HANLEY.

2000. Prevalence of the tick, Ixodes pacificus, on western fence

lizards, Sceloporus occidentalis: Trends by gender, size, season, site, and mite infestations. Journal of Herpetology 34: 160-163.

SCHÄUBLE, C.S. AND G.C. GRIGG.

1998. Thermal ecology of the Australian agamid Pogona barbata. Oecologia 114: 461-470.

SCHLESINGER, C.A. AND R. SHINE. 1994. Choosing a rock: perspectives of a bush-rock collector and a saxicolous lizard. Biological Conservation 67: 49-56.

SCHOENER, T.W.

1970. Nonsynchronous spatial overlap of lizards in patchy habitats. Ecology 51: 408- 418.

1975. Presence and absence of habitat shift in some widespread lizard species. Ecological Monographs 45: 233-258.

1977. Competition and the niche. Pages 35-136. in Biology of the Reptilia Vol. 7: Ecology and Behavior (C. Gans and D.W. Tinkle, eds.). Academic Press, London.

AND G.H. ADLER.

1991. Greater resolution of distributional complementarities by controlling for habitat affinities: a study with Bahamian lizards and birds. American Naturalist 137: 669-692.

SEXTON, O.J., R.M. ANDREWS, AND J.E. BRAMBLE.

1992. Size and growth rate characteristics of a peripheral population of Crotaphytus collaris (Sauria: Crotaphytidae). Copeia 1992: 968-980.

SHINE, R.

1999. Egg-laying reptiles in cold climates: determinants and consequences of nest temperatures in montane lizards. Journal of Evolutionary Biology 12: 918926. 
AND P. HARLOW.

1993. Maternal thermoregulation influences offspring viability in a viviparous lizard. Oecologia 96: 122-127.

, J.K. WEBB, M. FITZGERALD, AND J. SUMNER.

1998. The impact of bush-rock removal on an endangered snake species, Hoplocephalus bungaroides (Serpentes: Elapidae). Wildlife Research 25: 285-295.

SMITH, G.R.

1996a. Correlates of approach distance in striped plateau lizards (Sceloporus virgatus). Herpetological Journal 6: 56-58.

$1996 \mathrm{~b}$. Tail loss in the striped plateau lizard, Sceloporus virgatus. Journal of Herpetology 30: 552-555.

1996c. Mites on striped plateau lizards (Sceloporus virgatus: Phrynosomatidae): abundance, distribution and effects on host growth. Herpetological Natural History 4: 175-180.

1997. Substrate shifts in a population of striped plateau lizards, Sceloporus virgatus. Herpetological Journal 7: 116-118.

1998. Habitat-associated life history variation within a population of the striped plateau lizard, Sceloporus virgatus. Acta OEcologica 19: 167-173.

AND R.E. BALLINGER.

1994a. Thermal ecology of Sceloporus virgatus from southeastern Arizona, with comparison to Urosaurus ornatus. Journal of Herpetology 28: 65-69. 1994b. Temperature relationships in the high-altitude viviparous lizard, Sceloporus jarrovi. American Midland Naturalist 131: 181-189. 1995. Temperature relationships of the tree lizard, Urosaurus ornatus, from desert and low-elevation montane populations in the southeastern USA. Journal of Herpetology 29: 126-129.

SNELL, H.L., R.D. JENNINGS, H.M. SNELL, AND S. HARCOURT. 1988. Intrapopulation variation in predator-avoidance performance of Galápagos lava lizards: the interaction of sexual and natural selection. Evolutionary Ecology 2: 353- 369.

STAATS, C.M. AND J.J. SCHALL. 1996. Distribution and abundance of two malarial parasites of the endemic Anolis lizards of Saba Island, Netherlands Antilles. Journal of Parasitology 82: 409-413.

STAMPS, J.A.

1983. The relationship between ontogenetic habitat shifts, competition and predator avoidance in a juvenile lizard (Anolis aeneus). Behavioral Ecology and Sociobiology 12: 19-33. 
SWAIN, R. AND S.M. JONES.

2000. Maternal effects associated with gestation conditions in a viviparous

lizard, Niveoscincus metallicus. Herpetological Monographs 14: 432-440.

TÄLLEKLINT-EISEN, L. AND R.J. EISEN.

1999. Abundance of ticks (Acari: Ixodidae) infesting the western fence

lizard, Sceloporus occidentalis, in relation to environmental factors. Experimental and Applied Acarology 23: 731-740.

TINKLE, D.W.

1982. Results of experimental density manipulation in an Arizona lizard community. Ecology 63: 57-65.

TORR, G.A. AND R. SHINE.

1993. Experimental analysis of thermally dependent behavior patterns in the scincid lizard Lampropholis guichenoti. Copeia 1993: 850-854.

TRILLMICH, K.G.K. AND F. TRILLMICH.

1986. Foraging strategies of the marine iguana, Amblyrhynchus cristatus.

Behavioral Ecology and Sociobiology 18: 259-266.

TROYER, K.

1987. Small differences in daytime body temperature affect digestion of natural food in a herbivorous lizard (Iguana iguana). Comparative Biochemistry and Physiology 87A: 523-626.

VAN DAMME, R., D. BAUWENS, A.M. CASTILLA, AND R.F. VERHEYEN. 1990. Comparative thermal ecology of the sympatric lizards Podarcis tiliguerta and Podarcis sicula. Acta OEcologica 11: 503-512.

VANHOOYDONCK, B., R. VAN DAMME, AND P. AERTS.

2000. Ecomorphological correlates of habitat partitioning in Corsican lacertid lizards. Functional Ecology 14: 358-368.

VEGA, L.E., P.J. BELLAGAMBA, AND L.A. FITZGERALD. 2000. Long-term effects of anthropogenic habitat disturbance on a lizard assemblage inhabiting coastal dunes in Argentina. Canadian Journal of Zoology 78: $1653-1660$.

VIETS, B.E., A. TOUSIGNANT, M.A. EWERT, C.E. NELSON, AND D. CREWS. 1993. Temperature-dependent sex determination in the leopard gecko, Eublepharis macularis. Journal of Experimental Zoology 265: 679-683.

VITT, L.J. 
1995. The ecology of tropical lizards in the caatinga of northeast Brazil. Occasional Papers of the Oklahoma Museum of Natural History 1: 1-29.

AND T.C.S. AVILA-PIRES.

1998. Ecology of two sympatric species of Neusticurus (Sauria:

Gymnophthalmidae) in the western Amazon of Brazil. Copeia 1998: 570-582.

, J.P. CALDWELL, AND V.R.L. OLIVEIRA.

1998a. The impact of individual tree harvesting on thermal environments of lizards in Amazonian rain forest. Conservation Biology 12: 654-664.

AND DE CARVALHO.

1995. Niche partitioning in a tropical wet season: lizards in the lavrado area of northern Brazil. Copeia 1995: 305-329.

AND E.R. PIANKA.

1994. Lizard Ecology: Historical and Experimental Perspectives. Princeton University Press, Princeton.

S.S. SARTORIUS, T.C.S. AVILA-PIRES, M.C. ESPÓSITO, AND D.B. MILES. 2000. Niche segregation among sympatric Amazonian teiid lizards. Oecologia 122: 410-420.

, R.C. VAN LOBEN SELS AND R.D. OHMART. 1981. Ecological relationships among arboreal desert lizards. Ecology 62: 398410.

, P.A. ZANI, T.C.S. AVILA-PIRES, AND M.C. ESPÓSITO. 1998b. Geographical ecology of the gymnophthalmid lizard Neusticurus ecpleopus in the Amazon rain forest. Canadian Journal of Zoology 76: 16711680.

, AND J.P. CALDWELL.

1996. Behavioural ecology of Tropidurus hispidus on isolated rock outcrops in Amazonia. Journal of Tropical Ecology 12: 81-101.

, AND M.C. ESPÓSITO.

1999. Historical ecology of Amazonian lizards: implications for community ecology. Oikos 87: 286-294.

, AND A.C. MARINHO LIMA.

1997. Heliotherms in tropical rain forest: the ecology of Kentropyx calcarata (Teiidae) and Mabuya nigropunctata (Scincidae) in the Curuá-Una of Brazil. Journal of Tropical Ecology 13: 199-220.

WALDSCHMIDT, S. AND C.R. TRACY. 
1983. Interactions between a lizard and its thermal environment: implications for sprint performance and space utilization in the lizard Uta stansburiana. Ecology 64: 476- 484.

WEBB, J.K. AND R. SHINE.

2000. Paving the way for habitat restoration: can artificial rocks restore degraded habitats of endangered reptiles?. Biological Conservation 92: 93-99.

WIKRAMANAYAKE, E.D. AND G.L. DRYDEN. 1993. Thermal ecology of habitat and microhabitat use by sympatric Varanus bengalensis and V. salvator in Sri Lanka. Copeia 1993: 709-714.

ZIMMERMAN, L.C. AND C.R. TRACY.

1989. Interactions between the environment and ectothermy and herbivory in reptiles. Physiological Zoology 62: 374-409. 